\title{
Effects of the 6th September 2002 earthquake: damage amplification in the south-eastern sector of Palermo explained by GIS technology
}

\begin{abstract}
Maria Stella Giammarinaro $\left({ }^{1}\right)$, Vincenzo Canzoneri $\left({ }^{2}\right)$, Paola Vallone $\left({ }^{1}\right)$ and Alessandro Zuccarello $\left({ }^{1}\right)$
$\left.{ }^{1}\right)$ Dipartimento di Geologia e Geodesia, Università di Palermo, Italy
\end{abstract}

${ }^{2}{ }^{2}$ Laboratorio METRO s.r.l., Palermo, Italy

\begin{abstract}
During the 6th September 2002 earthquake the highest damage level in Palermo was observed in the SE sector. This is a recent urbanization area where reinforced concrete structures predominate. A detailed analysis of soil properties in Palermo was carried out by City-GIS to investigate a possible role of nearsurface geology on earthquake effects. City-GIS is a tool dedicated to natural hazard evaluation in urban areas. The availability of high density of well log data (stratigraphic and geotechnical) allowed a realistic modeling of surface geology and physical-mechanical properties that control the seismic response. In wide zones of the above mentioned sector of Palermo, outcropping terrains are composed of thin calcarenite layers, lying above remarkably thick siltyclayey sands that overlay the Numidian Flysch, commonly considered the bedrock of Quaternary sediments. Since silty-clayey sands feature greater deformability properties (Young's modulus) and smaller resistance properties (undrained cohesion and shear resistance angle) than Numidian Flysch, these zones of the SE sector exhibit high values of the acoustic impedance contrast. Moreover, a quite wide portion of the study area, crossed by the Oreto River, is characterized by very thick alluvial deposits. Here, the significant lateral variations of the lithostratigraphic geometry may be an additional cause of strong site effects.
\end{abstract}

Key words GIS - seismic response - site effects Palermo

\section{Introduction}

A seismic sequence located in the Southern Tyrrhenian Sea started on 6th September 2002 with a $M_{w} 5.9$ earthquake. The sequence lasted up to January 2003 producing more than 400 shocks. The mainshock caused locally diversi-

Mailing address: Dr. Maria Stella Giammarinaro, Dipartimento di Geologia e Geodesia, Università di Palermo, Via Archirafi 22, 90123 Palermo, Italy; e-mail: giammar@unipa.it fied effects in the Palermo area, 40 to $50 \mathrm{~km}$ from the epicenter.

Preliminary surveys showed a major damage density in the SE part of the city (Azzaro et al., 2002; Gasparini et al., 2002). The seismic activity did not cause structural damage, but disseminated cracks, collapse of ceilings and cornices were frequently observed.

Recently, Guidoboni et al. (2003) described the damage scenario in Palermo as produced by the three strongest earthquakes of the last three centuries (September 1726, March 1823, January 1940). According to Guidoboni et al. (2003), the surface geology and mechanical-physical properties of outcropping soils play an important role in the damage distribution in Palermo (see also Gi- 
ammarinaro et al., 1999, 2000, 2001; Catalano et al., 2000). Unfortunately there is no information on effects of the above mentioned historical seismic events to the SE sector of Palermo, since the urbanization of this sector is very recent.

In this paper, we analyse structure and mechanical properties of soils underlying the SE sector of the city, pointing out the presence of favourable conditions for significant site effects.

\section{Geological framework}

The Palermo urban area lies on Quaternary (Sicilian) deposits that unconformably overlie an Oligo-Miocene succession (Numidian Flysch). In the Quaternary deposits two main lithofacies have been recognized:

- Lithofacies 1 (bottom): Argille Azzurre Unit (Ruggieri et al., 1975). Calcareous nannofossils indicate a Late Emilian-Sicilian age.

- Lithofacies 2 (upper): calcarenites of the Quaternary age. It is generally accepted that these were deposited in a coastal environment.

Lithofacies 1 is found almost exclusively in the southern area of the city, while lithofacies 2 is present throughout the urban area.

Wide areas of the city also exhibit the presence of:

- alluvial deposits and fills related to rivers, some of which are no longer visible nowadays;

- sea deposits related to a eustatic variation of the sea level.

The main bulk contribution to the estimate of seismic response comes from the reconstruction of the geological structure. Due to the lateral variations of near surface geology, significant spatial variations of ground motion are expected.

\section{General observations}

The study area (about $2.5 \mathrm{~km}^{2}$ ) is part of the SE of the city and is bounded by Lincoln Street, the railway, the coast line and Giafar Street. The urbanized area of Palermo is shown in fig. 1a, where the investigated sector is marked in green.
The area can be considered at a high vulnerability level for the presence of major service structures like a regional hospital, the railway network, the considerable elements of historical-monumental heritage, the density of large multi-story buildings, and several handicraft industries (fig. 1b).

Moreover the study area is crossed by the Oreto River.

As already mentioned, the 6th September 2002 earthquake produced significant damage in the SE sector of Palermo. However, the damage distribution is not localized only close to the Oreto River, where it is expected, but covers the whole SE sector where inspections for the building safety were mostly required (fig. 1c).

As a first step of the work we determined how many and which lithotechnical types characterize the near surface geology of the SE sector.

For each succession we modeled the spatial trends of:

- geometries of the stratigraphic components;

- physical-mechanical properties for each lithotype of the successions.

The quite complex modeling process was performed by means of City-GIS, an urban GIS (Giammarinaro and Maiorana, 2001) designed and implemented at the Department of Geology and Geodesy of Palermo University.

Belonging to the class of oriented GIS, City-GIS is characterized by:

- an archive structured to store an oriented data model;

- tools and search keys designed to easily carry out hazard evaluation.

The datasets implemented in City-GIS can be displayed and queried on geo-referred cartography. This is a very useful tool for data analysis, as it extracts spatial correlations existing even among different kinds of data.

Up to now, about 2300 stratigraphies from mechanical boreholes, performed within the Palermo urban area, have been processed, stored and are currently managed by CityGIS.

Within the study area, the dataset density is sufficiently high to well define the surface geology and the physical-mechanical parameters characterising the different lithotypes (fig. 2). 


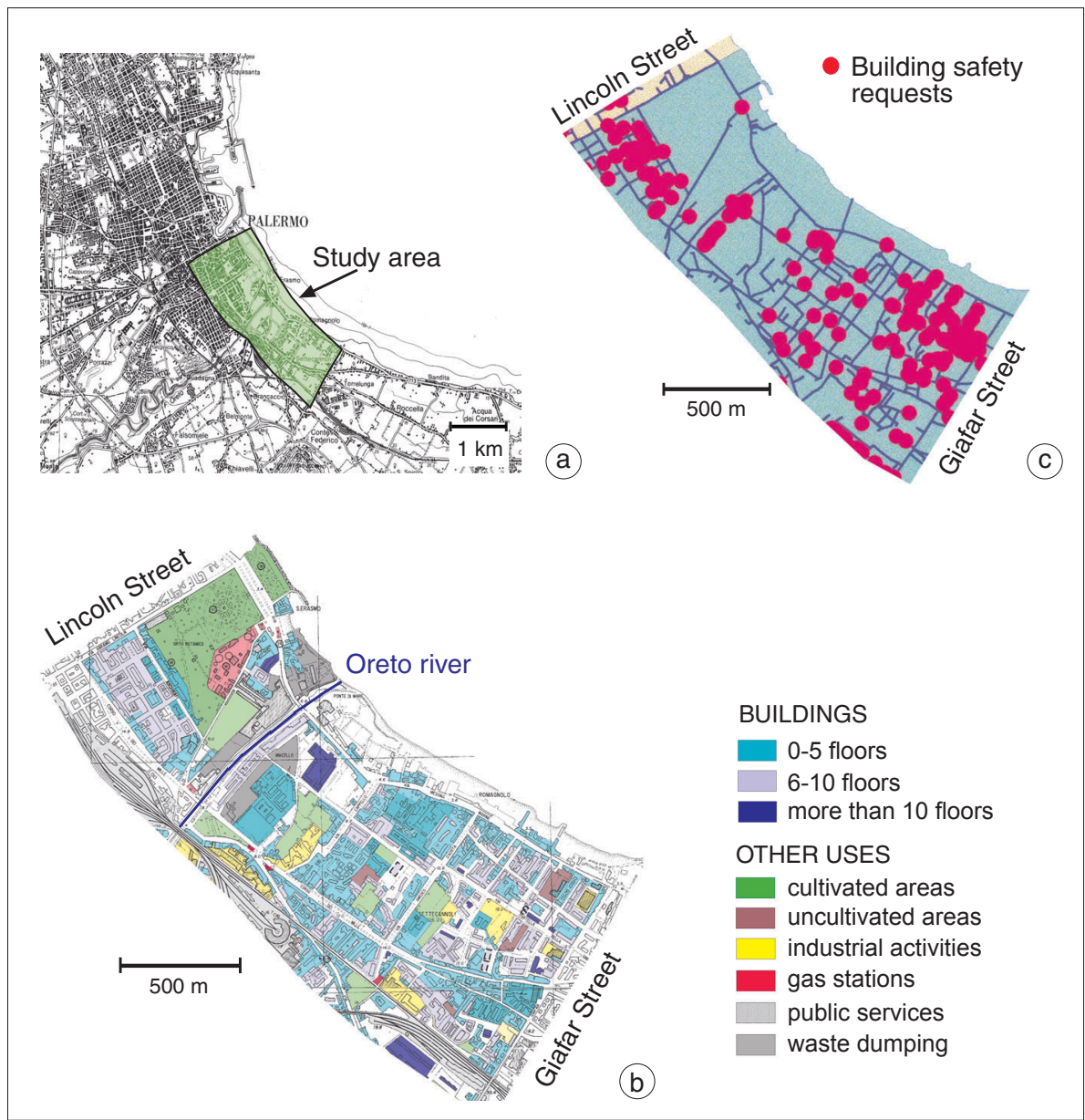

Fig. 1a-c. a) Palermo urban area, in green the study area; b) utilization of the grounds inside the study area; c) building safety requirements distribution in the investigated area (modified from a map drawn by Institutions).

\section{Stratigraphic analysis}

We first reconstructed the Numidian Flysch top. We considered a larger area in order to increase the number of boreholes intercepting the Oligo-Miocene formation, quite deep in this sector of Palermo.

We drew a map indicating the depth of the Numidian Flysch top (fig. 3). This map was elaborated using sixteen boreholes intercepting the Numidian Flysch top, shown in red in fig. 3. The map analysis reveals a general dipping in ESE and SSE directions, except for a limited zone affected by a structural high. Here the depth of the Numidian Flysch top is $22 \mathrm{~m}$.

Outside this limited zone, the depth values are between $60 \mathrm{~m}$ and $90 \mathrm{~m}$. Therefore the thickness of upper sediments must be between $60 \mathrm{~m}$ and $90 \mathrm{~m}$.

The lithostratigraphic database analysis shows that, inside Palermo SE sector, the two 


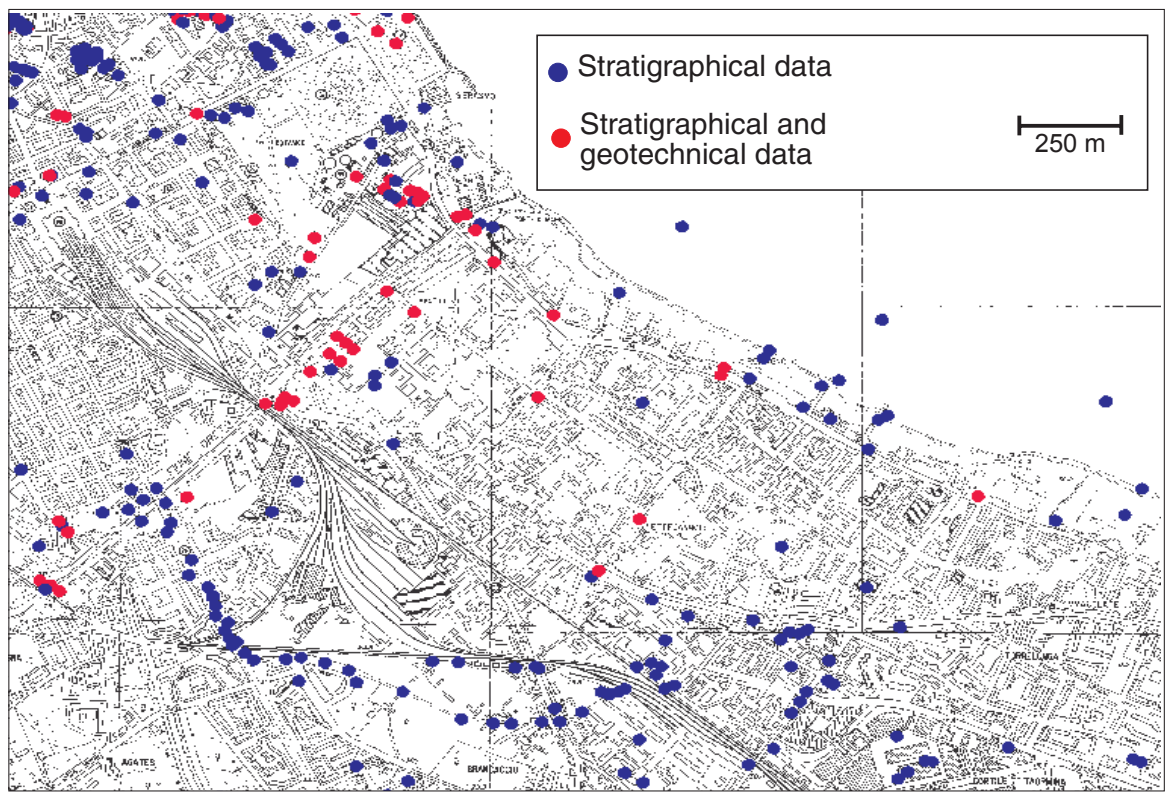

Fig. 2. Boreholes location; blue: stratigraphic data only; red: stratigraphic as well as geotechnical data.

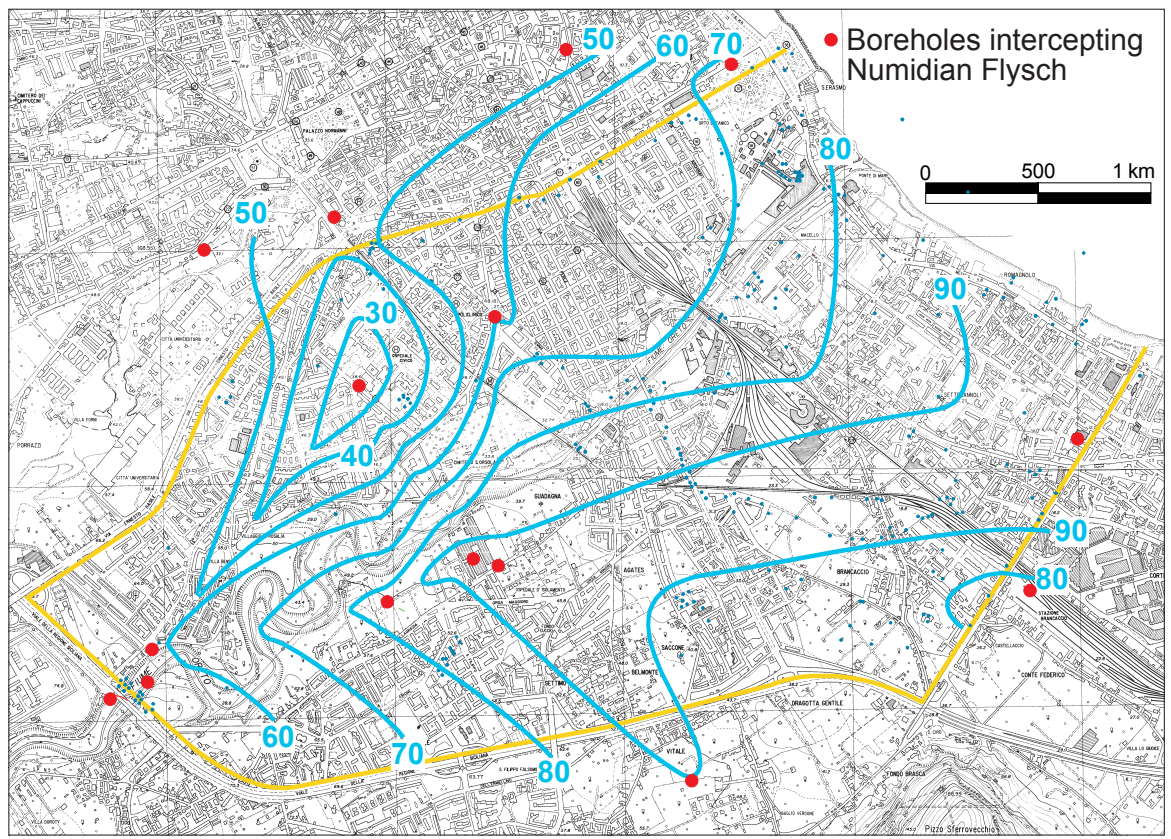

Fig. 3. Depth of the Numidian Flysch top and boreholes intercepting the Numidian Flysch top. 


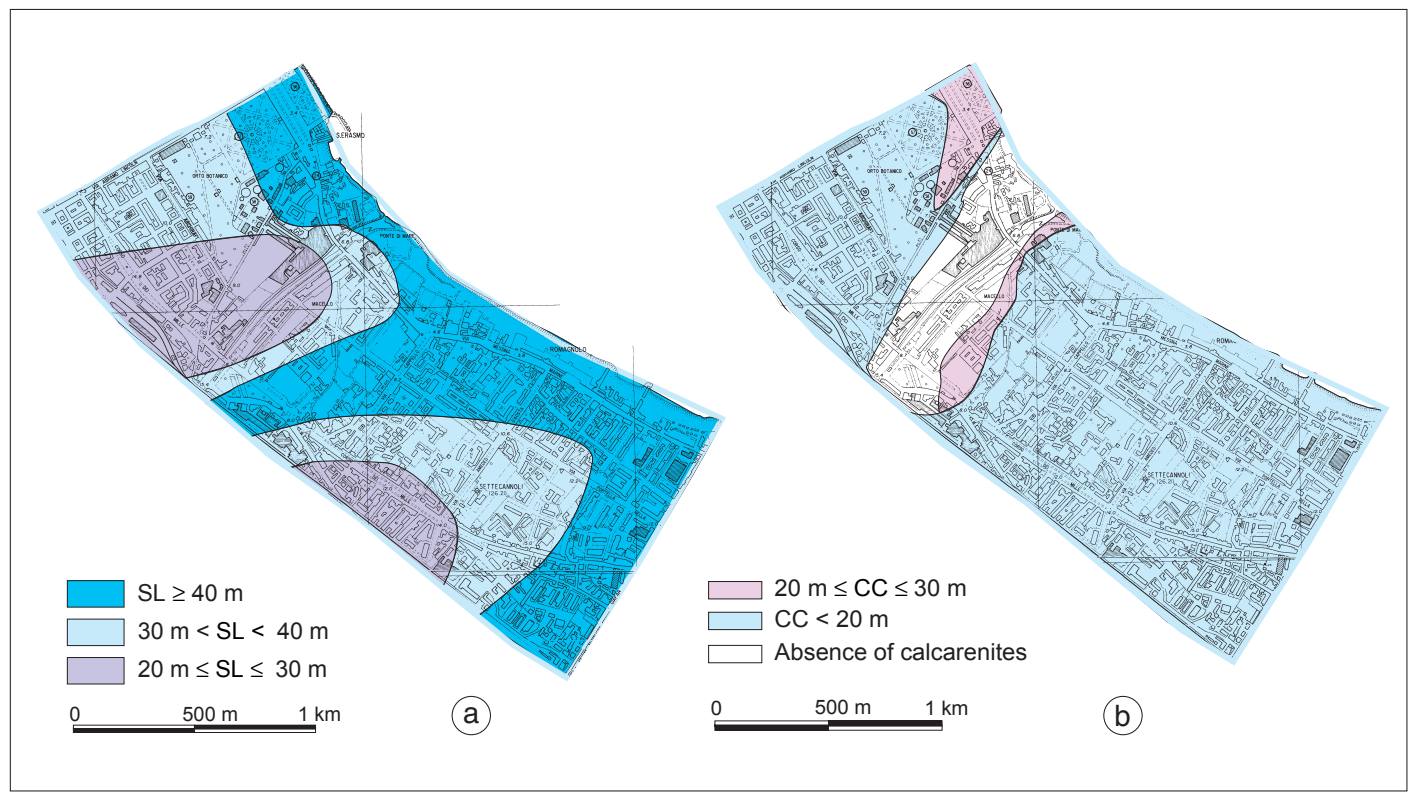

Fig. 4a,b. Thickness maps (a) silty clayey sands (SL); b) calcarenites (CC).

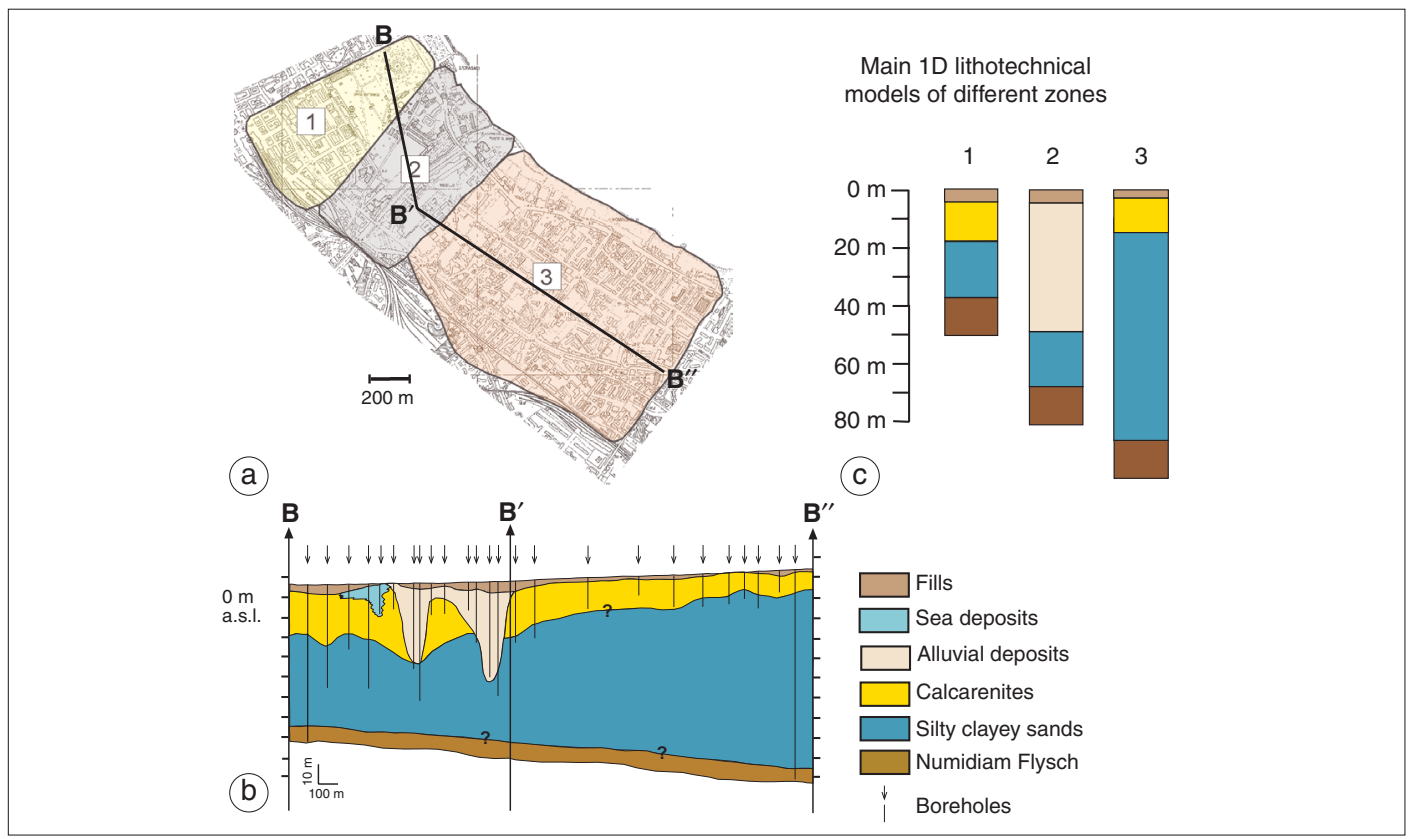

Fig. 5a-c. a) Zonation of the area; b) geological section; c) main lithotechnical model of each zone. 
main lithofacies of the Quaternary deposits exhibit different thickness trends.

The Argille Azzurre lithofacies exhibits the greatest thickness in the NE portion of the SE sector, where it can be thicker than $80 \mathrm{~m}$, while the calcarenitic one reachs its greatest thickness in the SW portion.

It is also possible to evaluate the thickness variability of Argille Azzurre (20-80 m) and of calcarenitic deposits $(0-30 \mathrm{~m})$ inside the investigated area.

For both lithotypes the thickness variability range was subdivided into intervals, each identified with different colors in the maps reported in the fig. $4 a, b$.

These maps show that the investigated area is prevalently affected by thick ( $>40$ m) Argille Azzurre and relatively thinner calcarenites $(<20 \mathrm{~m})$. Only inside two very limited areas, do calcarenitic deposits exceed $20 \mathrm{~m}$.

The study area is naturally divided into three zones by the Oreto River (fig. 5a): the portion on the left of the Oreto River, near the boundary of the City's Historical Center (zone 1), the portion crossed by the Oreto River (zone 2), the portion on the right of Oreto River (zone 3).

Zones 1 and 3 are described by the same lithotechnical succession: above the Numidian Flysch, we find Argille Azzurre, calcarenites and finally soft fills.
The geometry of the succession layers is different in the two zones. As already stated, Numidian Flysch reveals a general dipping in ESE and SSE directions with a consequent increase of the overlying sediment thickness.

Analysing the stratigraphic dataset we note that this increase affects almost only Argille Azzurre, that, inside zone 3, reach a thickness up to $85 \mathrm{~m}$.

Both zones 1 and 3 are affected by thin fills $(<5 \mathrm{~m})$; near the coast line, thin sea deposits may be locally present in zone 3 .

Zone 2, crossed by the Oreto River, is obviously described by a different lithotechnical model. Above the Numidian Flysch, in succession we find Argille Azzurre, Calcarenites, alluvial deposits (thickness up to $50 \mathrm{~m}$ ) and thin fills (thickness $<5 \mathrm{~m}$ ).

In the study area, the Argille Azzurre are lithotechnically silty clayey sands (SL). Later on we shall call them silty clayey sands.

We need a three strata model (silty clayey sands, calcarenites, fills) to describe zones 1 and 3, a four strata model (silty clayey sands, calcarenites, alluvial deposits, fills) to describe zone 2.

Inside zone 2, the calcarenites are prevalently eroded and the alluvial deposits directly overlie the silty clayey sands; therefore we consider this as the main lithotechnical model describing zone 2. Figure $5 \mathrm{c}$ reports the main lithotechnical model of each zone.

Table I. Variability fields of mechanical-physical properties exhibited by the different lythotipes.

\begin{tabular}{|c|c|c|c|c|c|c|c|}
\hline & Deformability & $\begin{array}{c}E \text { Young's } \\
\text { modulus } \\
\text { Cc compressibility } \\
\text { coefficient }\end{array}$ & $\begin{array}{l}\text { Undrained } \\
\text { cohesion }\end{array}$ & $\begin{array}{l}\text { Rupture } \\
\text { strength }\end{array}$ & Porosity & $\begin{array}{l}\text { Density } \\
\mathrm{Kg} / \mathrm{m}^{3}\end{array}$ & $\begin{array}{c}W_{n} \text { natural } \\
\text { content water } \\
W_{p} \text { plasticity } \\
\text { limit }\end{array}$ \\
\hline $\mathrm{L} / \mathrm{R}$ & High & $\begin{array}{l}E 2 \div 10 \mathrm{MPa} \\
\mathrm{Cc} 0.21 \div 0.63\end{array}$ & $\begin{array}{c}\text { Low } \\
15 \div 40 \mathrm{kPa}\end{array}$ & $50-100 \mathrm{kPa}$ & $\begin{array}{c}\text { High } \\
0.5 \div 0.7\end{array}$ & $1420-2040$ & $W_{n} / W_{p} \gg>1$ \\
\hline SL & Upper middle & $\begin{array}{c}E \quad 2 \div 20 \mathrm{MPa} \\
\text { Cc } 0.15 \div 0.30\end{array}$ & $\begin{array}{c}\text { Low } \\
15 \div 50 \mathrm{kPa}\end{array}$ & $50-200 \mathrm{kPa}$ & $\begin{array}{c}\text { Upper middle } \\
0.45 \div 0.6\end{array}$ & $1400-2080$ & $W_{n} / W_{p}>1$ \\
\hline $\mathrm{FN}$ & Lower middle & $\begin{array}{c}E 10 \div 100 \mathrm{MPa} \\
\text { Cc } 0.08 \div 0.13\end{array}$ & $\begin{array}{c}\text { High } \\
1 \div 2 \mathrm{MPa}\end{array}$ & $100 \div 300 \mathrm{kPa}$ & $\begin{array}{c}\text { Low } \\
0.3\end{array}$ & $1820-2130$ & $W_{n} / W_{p}<1$ \\
\hline $\mathrm{CC}$ & Low & E $1400 \div 15000 \mathrm{MPa}$ & & until $50 \mathrm{MPa}$ & & $1900-2400$ & \\
\hline
\end{tabular}


Using a large number of stratigraphies we worked out the geological section reported in fig. $5 \mathrm{~b}$, displaying the spatial evolution of each stratigraphic body geometry.

\section{Geotechnical analysis}

In a second step, we analysed the physical-mechanical properties of the lithotypes of each recognized lithotechnical model.

The relatively small extension of the inspected area allowed us to simplify the geotechnical classification of soils (Canzoneri et al., 2002), merging in a few classes all the lithotypes exhibiting similar values of deformability (Young's modulus) and strength (undrained cohesion and shear resistance angle).

Within this approximation, we considered four classes of lithotypes: silts and clayey silts (L), silty sands and sandy silts (SL), Numidian Flysch (FN) and calcarenites (CC).

For a selected portion of a geo-referred map and for each lithotype class, tools equipping City-GIS display the values of selected geotechnical parameters. We then defined, for each lithotype class, the variability range of deformability and resistance properties.

The results are reported in table I, showing how classes L and SL exhibit a quite similar mechanical behaviour, while class FN surely exhibits better mechanical properties.

Plots of plasticity limit $W_{p}$ versus natural water content $W_{n}$ are reported in fig. 6 for FN, in fig. 7 for SL and in fig. 8 for L. It shows a ratio $W_{n} / W_{p}>>1$ for $L$ class samples, $>1$ for SL class samples and $<1$ for FN class samples, indicating that the latter are less water saturated and deformable than the others.

Fig. 6. Plasticity limit versus natural water content for FN class.

Fig. 7. Plasticity limit versus natural water content for SL class.

Fig. 8. Plasticity limit versus natural water content for $L$ class.
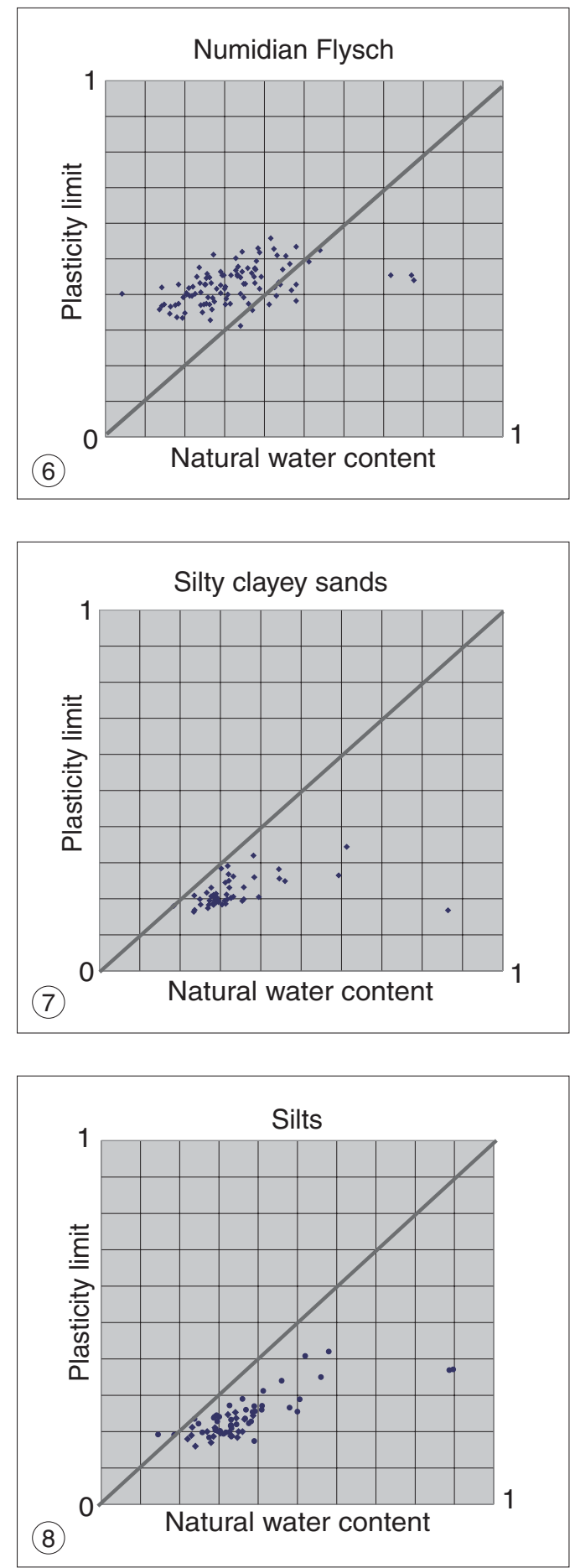
As known, the site effects amplitude is strongly affected by acoustic impedance contrast, a quantity dependent on densities and on $S$-wave speed of the lithotypes met by the seismic signal.

In order to evaluate the $S$ waves speed for the different lithotypes, we analysed the results given by the edometric compression tests. These data determine Young's modulus $E$.

By means of the relationships $\mu=E /[2(1+$ $+\sigma)]$ and $V_{s}=\sqrt{\mu / \rho}(\mu$ rigidity modulus, $E$ Young's modulus, $\sigma$ Poisson's modulus, $\rho$ density), an indirect evaluation of the $S$-waves speed can be obtained.

L and SL classes: Young's modulus is always between 2-10 MPa for L class, between 2-20 MPa for SL class. For both classes, L and SL, Young's modulus exhibits a saturating behaviour with depth, at $10 \mathrm{MPa}$ and $20 \mathrm{MPa}$ respectively.

Using the density values obtained from samples taken inside the study area and assuming Poisson's modulus values between 0.35 and 0.3 , we calculated the speed of the $S$-waves.

We obtained $S$-waves speed values between $20 \mathrm{~m} / \mathrm{s}$ and $60 \mathrm{~m} / \mathrm{s}$ for samples belonging to $\mathrm{L}$ class, and between $20 \mathrm{~m} / \mathrm{s}$ and $100 \mathrm{~m} / \mathrm{s}$ for samples belonging to SL class.

CC class: a large variability range (1400 MPa-15000 MPa) of Young's modulus was obtained for calcarenitic deposits, that exhibit, inside the area, a rich facies variety, going from very friable to very compact.

Assuming Poisson's modulus values between 0.2 and 0.25 and using experimentally measured density values, we obtained values of the $S$-waves speed between $400 \mathrm{~m} / \mathrm{s}$ and $1850 \mathrm{~m} / \mathrm{s}$.

In the study area, the prevalent facies of calcarenitic deposits is set up by alternating sands and calcarenites. A low $S$-waves speed value is thus expected.

FN class: in the study area the Numidian Flysch is quite deep (60-90 m). For this reason, experimental measures of Young's modulus were not available.

Although the available Young's modulus data for Numidian Flysch are affected by a major dispersion, we can note, nevertheless, an increasing trend with depth.

Edometric compression tests on Numidian Flysch samples taken at depth between a few meters and $30 \mathrm{~m}$ gave Young's modulus values between $20 \mathrm{MPa}-100 \mathrm{MPa}$.

The Numidian Flysch top in the study area is much deeper.

Therefore, in the study area, reliable Young's modulus experimental values for Numidian Flysch are not available. Nevertheless, it is possible to assert that $E_{F N} / E_{S L}$ and $E_{F N} / E_{L}$ ratio values are certainly greater than 5 and 10 respectively. Consequently, the acoustic impedance contrast $Z_{F N} / Z_{L}$ and $Z_{F N} / Z_{S L}$ can be greater than 5 .

In the study area, conditions suitable to site effects may therefore occur.

\section{Transfer functions in $1 \mathrm{D}$ approximation}

The evaluation of the transfer functions associated with the main lithotechnical successions recognized in the area can be useful for a preliminary assessment of the local seismic response variability.

A correct determination of the local seismic response is a complex problem because it is necessary to take into account source as well as propagation effects.

The source location, the subsurface topography (Bouchon, 1973), the lateral heterogeneities and the nonlinear behaviour of the sediments could produce a local seismic response very different from that expected only on the basis of the 1D structure (Field, 1996). However, one of the main bulk contributions to the seismic response comes from the local 1D structure.

Our present purpose is to establish whether or not the properties of the local lithotechnical succession could yield site effects (Borcherdt, 1970; Sanchez-Sesma and Esquivel, 1979).

An oversimplified method, the HaskellThomson algorithm (Haskell, 1960), is used.

The assumption of a linear soil response is acceptable for modeling ground motion in Palermo during the 6th September 2002 earthquake because it did not exceed $0.1 \mathrm{~g}$ (G. Calderoni, private communication).

We modeled the SH transfer functions using the 1D Haskell Thomson approach, for nearly vertical incidence. The algorithm uses the thickness, speed and density of each succession layer. 
For each recognized lithotechnical model the SH transfer function 1D was calculated.

The uncertainties concerning the $S$-waves speed value for Numidian Flysch advised us to determine the 1D transfer function using two different $S$ waves speed values for Numidian Flysch.
The transfer function of a single layer of silty clayey sands over half space is reported in fig. 9a. If we add a softer, alluvial deposit layer (zone 2 model), we obtain the transfer function of fig. 9b, that shows an amplitude increase in comparison with fig. 9a.
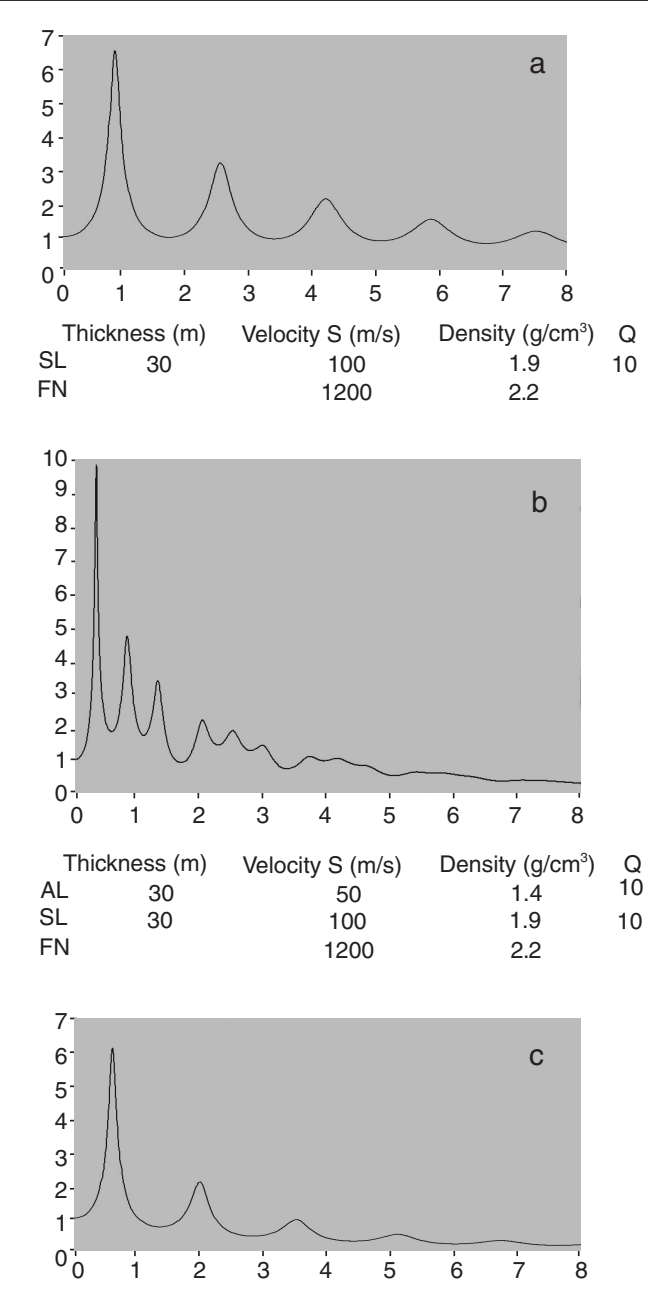

Thickness $(\mathrm{m}) \quad$ Velocity $\mathrm{S}(\mathrm{m} / \mathrm{s}) \quad$ Density $\left(\mathrm{g} / \mathrm{cm}^{3}\right)$

\begin{tabular}{lcccc}
\multicolumn{2}{c}{ Thickness $(\mathrm{m})$} & Velocity S $(\mathrm{m} / \mathrm{s})$ & Density $\left(\mathrm{g} / \mathrm{cm}^{3}\right)$ & $\mathrm{Q}$ \\
$\mathrm{CC}$ & 10 & 400 & 2.1 & 10 \\
SL & 30 & 100 & 1.9 & 10 \\
FN & & 1200 & 2.2 &
\end{tabular}

(a)

(b)
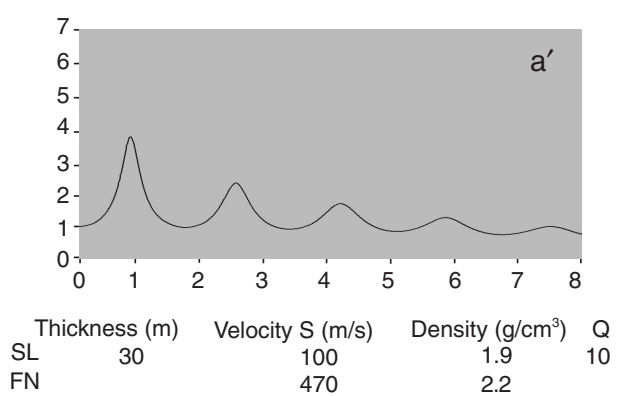

FN $\quad 470$

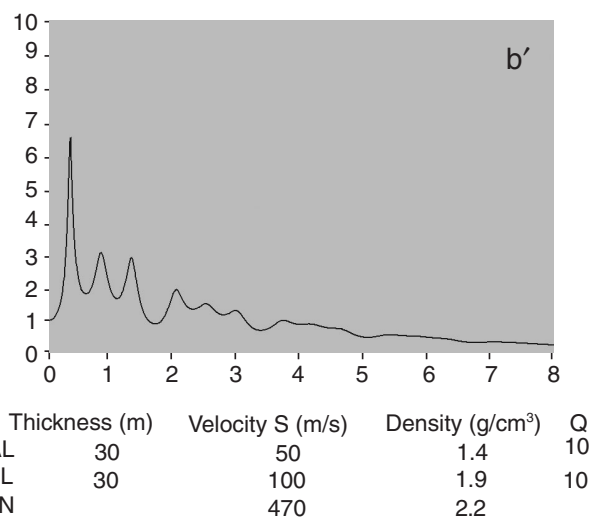

(C)

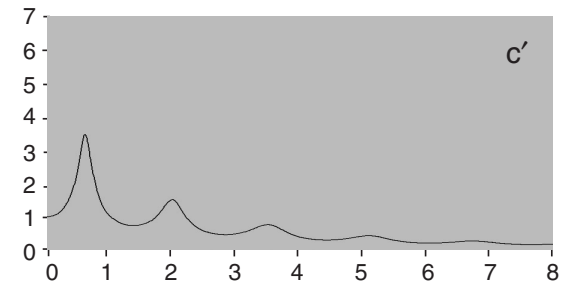

\begin{tabular}{lcccc}
\multicolumn{2}{c}{ Thickness $(\mathrm{m})$} & Velocity S $(\mathrm{m} / \mathrm{s})$ & Density $\left(\mathrm{g} / \mathrm{cm}^{3}\right)$ & $\mathrm{Q}$ \\
$\mathrm{CC}$ & 10 & 400 & 2.1 & 10 \\
$\mathrm{SL}$ & 30 & 100 & 1.9 & 10 \\
$\mathrm{FN}$ & & 470 & 2.2 &
\end{tabular}

Fig. 9a-c. SH 1D transfer functions of the lithotechnical models. 
In contrast, by adding a layer $(10 \mathrm{~m})$ of harder calcarenite (zone 1 and zone 3 model) we obtain the transfer function of fig. 9c that shows a smaller amplitude compared with fig. 9a.

The worsening of mechanical properties of alluvial deposits in comparison with silty clayey sands and the absence of calcarenites deposits can explain the differences between fig. $9 \mathrm{~b}$ and $9 \mathrm{c}$.

Many factors may compete or cooperate to build up the complete seismic response of a site.

So only the application of advanced methods for realistic evaluation of ground motion can lead to reliable microzoning. Nevertheless the rough and only qualitative zoning provided by Haskell-Thomson method indicates the study area potentially exposed to site effects, expected to be more effective inside zone 2 .

\section{Comparison with real seismic effects}

The greatest damage after the 6th September 2002 was not only along the Oreto River deposits. Preliminary surveys (Azzaro et al., 2002) showed a major level of damage inside the whole SE Palermo sector (figs. 1a and 5a), where the silty clayey sands thickness exceeds $30 \mathrm{~m}$ (fig. 4a), while calcarenitic deposits thickness is less than $20 \mathrm{~m}$.

The 1D transfer function reported in fig. 9c is associated with this lithotechnical succession model. Therefore site effects can be produced as well as inside zones 1 and 3 , according to the major level of the damage observed after 6th September 2002 earthquake.

The most severe damage (breakdown of ceilings, passing lesions in dividing walls) was observed in the lined up buildings shown in fig. 10a,b, in which boreholes intercepting alluvial deposits are marked in a different colour.

By means of the available datasets, a geological section has been worked out (fig. 10c).

The analysis of this geological section shows the thickest alluvial deposits underneath the mentioned buildings, also affected by a remarkable lateral heterogeneity.
In this zone, in the past, the Oreto River exhibited meanders where the alluvial sediments were preferentially deposited. That is why we find thick (up to $40-50 \mathrm{~m}$ ) alluvial deposits in areas no longer crossed by the water course.

The geological section (fig. 10c) also shows a total absence of calcarenites.

Therefore the lithotechnical succession model underneath the mentioned buildings is characterized by the 1D transfer function reported in fig. $9 \mathrm{~b}$, certainly suitable to produce major site effects.

The geometry of these buildings could also be causally related to the greater level of observed damages. These buildings exhibit a rectangular plant, with the longer side approximately oriented in the NE-SW direction.

As far as the aims of the present work are concerned, a building with an elongated rectangular plan (as in the present case) may be approximated with a homogeneous elastic bar.

As known, the lowest frequency normal modes of the homogeneous elastic bar exhibit a polarization orthogonal to the bar length. In engineering terms, this is expressed by saying that the lowest structural rigidity is in the direction of the building width, in the present case NW-SE direction (fig. 10b).

With reference to the geographic location of the source (fig. 10d) and of the observation point (SE sector of Palermo) the incoming direction of seismic waves is prevalently NE-SW.

SH-waves (horizontal component of transverse waves) incoming from that direction thus exhibit at the observation point a polarization that is prevalently NW-SE, orthogonal to the incoming direction (NE-SW).

The investigated buildings exhibit an elongated rectangular plan almost parallel (fig. 10a-d) to the incoming direction of seismic waves. There is, thus, a nearly perfect match between the stimulus ( $\mathrm{SH}$-waves) polarization and the said lowest frequency normal modes of the buildings.

These geometrical relationships are best evidenced in a GIS environment. 


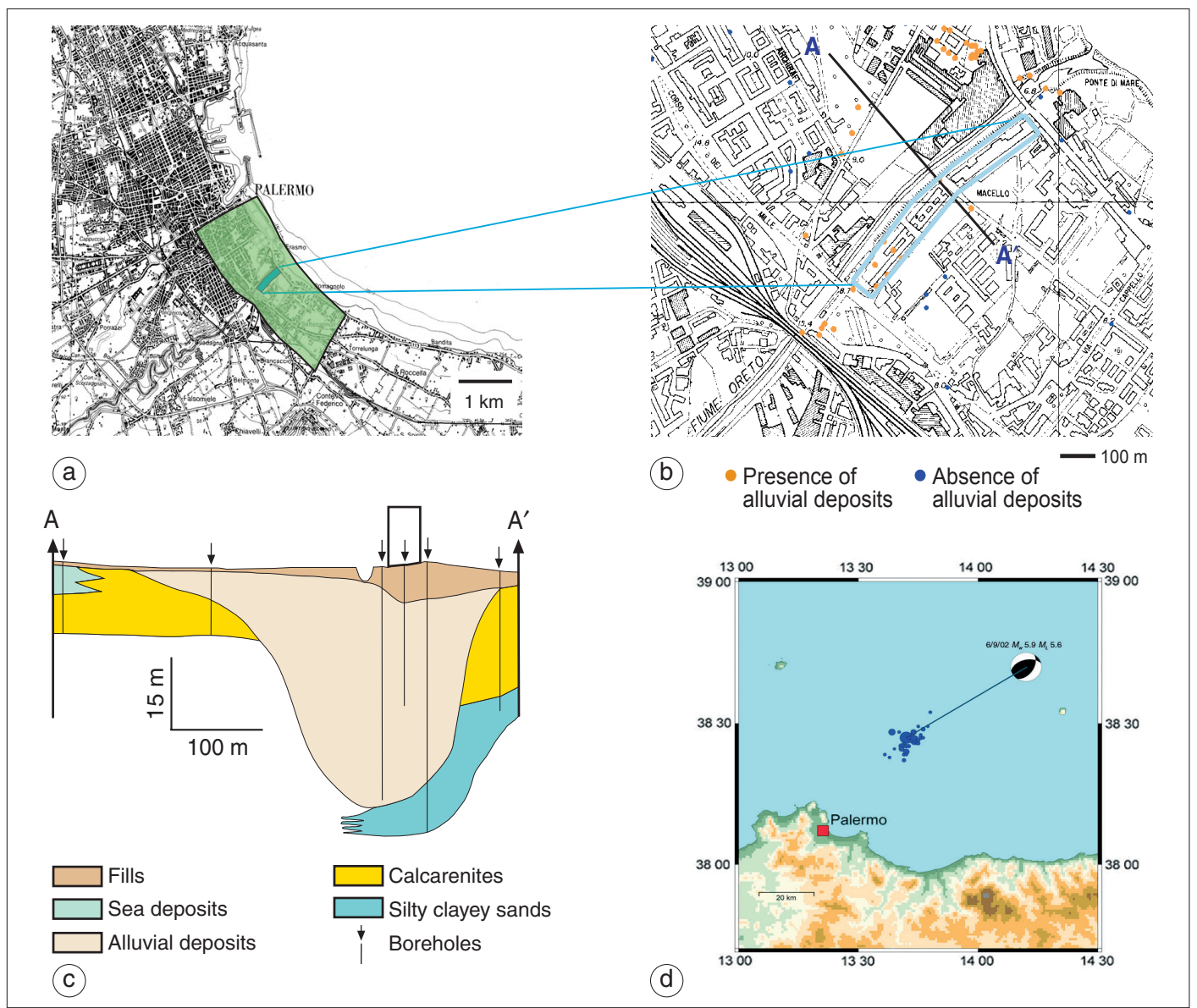

Fig. 10a-d. a,b) Buildings particularly damaged by 6th September 2002 earthquake; orange dots: boreholes with presence of alluvial deposits; blue dots: boreholes with absence of alluvial deposits; c) geological section across the site; d) localization of shocks with $M>3.1$, from the INGV web site.

\section{Conclusions}

A very large amount of geological and geotechnical data, collected during several restoration works and extensions and updating of service networks, are spread across a large number of offices operating in the territory.

Usually these data are affected by considerable inhomogeneities to be ascribed to different sources; however, encoding, digitizing and implementing them in a dedicated GIS can allow the elaboration of reliable datasets.
The possibility to display data in the mutual spatial relationships facilitate data consistency control. GIS technology is thus a highly effective tool in setting up reliable datasets.

The analysis of these datasets defines the trend of the major quantities controlling seismic hazard, mainly with the help of a GIS application equipped with tools and research keys to easily carry out elaborations specific to the natural hazard assessment process.

Following the described procedure, very reliable stratigraphic and geotechnical 
datasets were elaborated for Palermo urban area.

These datasets were implemented in CityGIS, a simple and low cost application GIS, developed to support seismic hazard assessment.

We set up a detailed analysis of the uppermost sediment layers in the Palermo SE sector, in which 6th September 2002 earthquake produced damages greater than in the surroundings.

The possibility to work on geo-referred data allowed us to examine and compare, in the correct mutual spatial relationships, data related to damage and data related to stratigraphic and geotechnical characteristics of the soils.

The availability of a high density stratigraphic dataset allowed us to set up, for the investigated area, a detailed reconstruction of the 2D and 3D stratigraphic succession.

The main lithotechnical succession models were identified and their SH transfer functions for nearly vertical incidence calculated, using the 1D Haskell Thomson approach.

The available geotechnical dataset allowed to use, as input parameters, the values of a number of quantities measured on samples collected inside the investigated area.

Two models, for the geometry and the mechanical properties of the component lithotypes, yield favourable conditions for site effects. The first model describes the Oreto River zone. Here the very thick alluvial deposits yield a large amplification of the seismic signal.

Aftershock seismograms recorded in the Oreto Valley (Azzara et al., 2002) showed a significant difference in amplitude on the horizontal components, thus validating the conclusions on the role of local geology inferred from the GIS analysis.

The other model described a large portion of the investigated area, affected by thick silty clayey sands, underlying calcarenitic deposits thinner than $20 \mathrm{~m}$.

The high density of the geothecnical dataset and the utilities of the developed GIS application disclosed the differences between the Numidian Flysch clays and the Argille Azzurre clays, showing that the latter exhibit a higher water saturation level and are characterised by a lower Young's modulus.
On going from the Numidian Flysch towards the silty clayey sands, the propagation speed of seismic signal decreases and consequently an amplification of the seismic signal occurs. The thin and friable overlying calcarenitic deposits are unable to compensate this effect.

To conclude, favourable conditions to the activation of site effects, highlighted in the historic centre, also exist inside the city SE sector.

Historical seismic events did not produce heavy effects here because this area was not urbanised in those times.

Our results indicate that oriented GIS is an innovative method for the seismic zonation of urban areas exhibiting a great variability of surface geology also on a local scale.

\section{Acknowledgements}

This work was funded by the MIUR (60\% 1998, 1999; Cipe 488).

The authors thank Prof. R. Catalano and Prof. A. Rovelli for many fruitful discussions.

\section{REFERENCES}

Azzara, R.M., M. Alletti, G. Cultrera, G. D'Anna, M.S Giammarinaro, L. Passafiume, A. Rovelli and P. ValLONE (2002): Risposta sismica in aree urbane: il terremoto di Palermo del 6 Settembre 2002, in $21^{\circ}$ Convegno Nazionale GNGTS, Riassunti estesi, 209-211.

Azzaro, R, R. CAmassi, S. D'Amico, A. Mostaccio and L. SCARFI (2002): Il terremoto di Palermo del 6 settembre 2002: effetti macrosismici, in $21^{\circ}$ Convegno Nazionale GNGTS, Riassunti estesi, 115-117.

BORCHERDT, R.D. (1970): Effects of local geology on ground motion near San Francisco Bay, Bull. Seismol. Soc. Am., 60, 29-61.

Bouchon, M. (1973): Effect of topography on surface motion, Bull. Seismol. Soc. Am., 63, 615-632.

Canzoneri, V., M.S. Giammarinaro, G. Gugliuzza and P. VALLONE (2002): Area urbana palermitana: analisi delle proprietà geotecniche dei terreni supportata da tecnologia GIS, in Opere Geotecniche in Ambiente Urbano (Patron Editore, Bologna), 37-44.

CATAlano, R. and M.S.Giammarinaro (2000): Riconoscimento e localizzazione delle differenti strutture 1D presenti all'interno del Centro Storico della città di Palermo: effetti attesi sulla risposta sismica locale, in Scenari di Pericolosità Sismica ad Augusta, Siracusa e Noto, edited by L. DECANINI and G.F. PANZA (CNRGNDT), 178-193.

FIELD, E.H. (1996): Spectral amplification in a sedimentfilled valley exhibiting clear basin edge induced waves, Bull. Seismol. Soc. Am., 86, 991-1005. 
Gasparini, C., P. Tosi and V. De Rubeis (2002): Il terremoto della Sicilia Settentrionale del 6 settembre 2002 analisi dei risentimenti macrosismici a scala regionale e locale (Palermo), in $21^{\circ}$ Convegno Nazionale GNGTS, Riassunti estesi, 216-217.

Giammarinaro, M.S. and S. MAIORANA (2001): Una applicazione GIS dedicata ai sistemi urbani, Geologi di Sicilia, n. 3, 21-25.

Giammarinaro, M.S., R. Spotorno, A. Sulli and R.CATALANO (1999): Analisi litostratigrafica del sottosuolo de Centro Storico della città di Palermo finalizzata alla stima della pericolosità sismica dell'area, Naturalista Sicil., s. IV, XXIII (3/4), 335-337.

Giammarinaro, M.S., V. Canzoneri, R. Spotorno, A. SulLI and R. Catalano (2000): Historical Centre of Palermo: effects of the lithotechnical successions on the bulk contribution to seismic response, Mem. Soc. Geol. It., 55, 439-447.

Giammarinaro, M.S., E. Guidoboni, S. Maiorana and A. Rovelli (2001): A GIS system as a tool for the inte- grated analysis of geological data and seismic effects: historic centre of Palermo, in Proceedings of IEEE, 01EX482, 288-292.

Guidoboni, E., D. Mariotti, M.S. Giammarinaro and A. RovelLi (2003): Identification of amplified damage zones in Palermo, Sicily (Italy) during the earthquakes of the last three hundred years, Bull. Seismol. Soc. Am., 93 (4), 1649-1669.

HASKELL, N.A. (1960): The dispersion of surface waves in multilayered media, Bull. Seismol. Soc. Am., 43, 17-34.

RugGieri, G and R. SPRovieri (1975): Ricerche sul Siciliano di Palermo: le argille del fiume Oreto, Boll. Soc. Geol. It., 94, 1613-1622.

SANCHEZ-SESMA, F.J. and J. Esquivel (1979): Ground motion of alluvial valleys under incident plane $\mathrm{SH}$ waves, Bull. Seismol. Soc. Am., 69, 1107-1120.

(received December 16, 2002; accepted May 9, 2003) 
